\title{
The diversity of unique 1,4,5,6-Tetrahydro-2-methyl-4- pyrimidinecarboxylic acid coding common genes and novel Universal stress protein in Ectoine TRAP cluster (UspA) in 32 Halomonas species
}

\section{Bhagwan Rekadwad ( $\square$ rekadwad@gmail.com )}

Yenepoya Research Centre, Yenepoya (Deemed to be University), University Road, Deralakatte, Mangalore 575018, Karnataka, India https://orcid.org/0000-0002-0954-0180

Wen-Jun Li

School of Life Sciences, Sun Yat-Sen University, Guangzhou, 510275, China

\section{Rekha PD}

Yenepoya Research Centre, Yenepoya (Deemed to be University), University Road, Deralakatte, Mangalore 575018, Karnataka, India

\section{Research Article}

Keywords: Ectoine, Life under extreme conditions, Saline environments, Single-copy genes, Ancient bacteria and Archaea, Bioactive compounds

Posted Date: May 19th, 2021

DOI: https://doi.org/10.21203/rs.3.rs-537023/v1

License: (a) (1) This work is licensed under a Creative Commons Attribution 4.0 International License. Read Full License

Version of Record: A version of this preprint was published at BMC Research Notes on August 3rd, 2021. See the published version at https://doi.org/10.1186/s13104-021-05689-3. 


\section{Abstract}

Objectives To decipher the diversity of unique ectoine-coding housekeeping genes in the genus Halomonas.

Results In Halomonas, 1,4,5,6-Tetrahydro-2-methyl-4-pyrimidinecarboxylic acid has a crucial role as a stress-tolerant chaperone, a compatible solute, a cell membrane stabilizer, and a reduction in cell damage under stressful conditions. Apart from the current 16S rRNA biomarker, it serves as a blueprint for identifying Halomonas species. Halomonas elongate $1 \mathrm{H} 9$ was found to have 11 ectoine-coding genes. The presence of a superfamily of conserved ectoine-coding among members of the genus Halomonas was discovered after genome annotations of 93 Halomonas spp. As a result of the inclusion of 11 single copy ectoine coding genes in 32 Halomonas spp., genome-wide evaluations of ectoine coding genes indicate that 32 Halomonas spp. have a very strong association with Halomonas elongata $1 \mathrm{H} 9$, which has been proven evidence-based approach to elucidate phylogenetic relatedness of ectoine-coding child taxa in the genus Halomonas. Total 32 Halomonas species have a single copy number of 11 distinct ectoine-coding genes that help Halomonas spp. produce ectoine under stressful conditions. Furthermore, the existence of the Universal stress protein (UspA) gene suggests that Halomonas species developed directly from primitive bacteria, highlighting the role of Halomonas species in evolutionary terms.

\section{Introduction}

1,4,5,6-Tetrahydro-2-methyl-4-pyrimidinecarboxylic acid is a natural pigment accumulates within the cytoplasm of salt-loving bacteria (e.g. genus Ectothiorhodospira) having osmoregulatory function termed as 'ectoine' (Galinski et a., 1985). The moderately halophilic members of family Halomonadaceae displays osmoadaptation facilitated by betaine, ectoine (Cánovas et al., 1996) and hydroxyectoine (Vargas et al., 2008). Family Halomonadaceae possess total 18 child taxa. Of these, 14 child taxa are with validly published and correct name, while 16 child taxa are with validly published name including synonyms under the International Code of Nomenclature of Prokaryotes (ICNP). On similar note, Genus Halomonas represented by 114 type strains with 112 candidates with validity published name and correct name and 10 with synonyms. Also, three species are orthographic misspelled variant and 18 invalidated species were not validated by ICNP (LPSN, 2021). Halomonas species are producer of, biotechnologically important biomolecules, ectoine. Being suspended in the cytoplasm, ectoine and hydroxyectoine coded by Halomonas species has benefits to cell. It acts as stress tolerant chaperones, as a compatible solute, stabilize of cell membrane and reduce cell damage. Moreover, ectoine and hydroectoines are high-value chemicals and exploited for cosmetics, immune protection, stabilization of antibodies, anti-inflammatory and tissue protective agent, for co-production of bioplastic polyhydroxybutyrate (Melmer and Schwarz, 2009), skin raging and protectant (wind, humidity, radiation and extreme temperatures), whole cell and macromolecule protection (freezing, drying, high salinity, heat stress, oxygen radicals, radiation and denaturing agents), protein protection and biomedical applications (Pastor et al., 2010). Various applications of Halomonas species reflect presence of diverse gene profiles in their genomes. It is therefore important to evaluate indicative signatures of ectoine coding genes among the genus Halomonas that governs them to perform vital biological function under extreme environmental conditions.

In current study, a blue print of ectoine coding genes was identified from Halomonas elongata. Genome annotations of existing Halomonas spp., uncovered existence of some common genes that codes ectoine (s) among members of the genus Halomonas. Thus, genome-wide evaluations of ectoine coding genes were also examined. We also analyzed highly close 32 Halomonas spp., with Halomonas elongata $1 \mathrm{H} 9$, which has phylogenetic related ectoine coding child taxa inferred using identified single copy genes.

\section{Methods}

\section{8 type strains 16S rRNA genes and ninety-four Halomonas spp., genomes}

One hundred twenty-eight 16S rRNA genes of type strains and ninety-four complete genomes and reference sequences of Halomonas spp., were obtained from LPSN and NCBI genome database. 


\section{Radar chart}

Halomonas spp., possesses multiple quantitative variables (species in particular) i.e. variable genome length/data points for visualization. Radar chart makes the way easy to compare the intra-species variable length to see similar values and find high or low scoring within outliers in the genus.

\section{RAST Genome analysis}

Complete genome sequences of Ectothiorhodospira haloalkaliphila ATCC 51935 (CP007268), Halomonas elongata 1H9 (NC_014532), Halorhodospira halochloris DSM 1059 (AP017372) and Halorhodospira halophila SL1 (CP000544) analyses done using RAST v2.0 (https://rast.nmpdr.org/). RAST server is a SEED-based National Microbial Pathogen Database Resource (NMPDR), prokaryotic genome annotation service, to predict system coverage, subsystem category distribution and subsystem feature count (Brettin et al., 2015).

\section{Identification of protein families and single copy genes}

Protein families and single-copy genes in 93 Halomonas spp., were identified using PATRIC 3.6.9

(https://www.patricbrc.org/). PLfams within the genus were computed with MCL inflation $=3.0$ to obtain higher sequence similarity and better specificity for intra-genus/species close comparisons.

\section{Selecting single copy number genes}

PLfams of 1,4,5,6-Tetrahydro-2-methyl-4-pyrimidinecarboxylic acid coding genes among 93 Halomonas spp., were extracted. Common genes coded by Halomonas species were selected for analysis. The topology of the phylogenetic tree generated using concatenated sequences was compared with the topology of 16S rRNA based Halomonas spp., child taxa tree.

\section{Phylogeny reconstruction and topology analysis}

The evolutionary history of one hundred twenty-eight16S rRNA and 33 Halomonas single-copy genes were inferred using standalone tool MEGA X with 1000 bootstrap analysis followed by best scoring ML, NJ and ME tree. The Jukes-Cantor method and are in the units of the number of base substitutions per site. The closest child taxa of biotechnological important ectoine producing Halomonas elongata $1 \mathrm{H} 9$ were deciphered. It helps for phylogenetic analysis and topology comparison to delineate nearest species and 1,4,5,6-Tetrahydro-2-methyl-4-pyrimidinecarboxylic acid gene coding species.

\section{Results}

\section{Phylogenetic analysis of 16S rRNA genes in the genus Halomonas}

Halomonas elongata $1 \mathrm{H} 9$ is a saline bacterium known for 1,4,5,6-Tetrahydro-2-methyl-4-pyrimidinecarboxylic acid (ectoine) producing abilities under extreme environmental condition.

RAST genome analysis of the Halomonas elongata $1 \mathrm{H} 9$ shows that various subsystem feature counts consists of different pathways (Figure 3). Similarly, other members of the genus Halomonas are known to code and produce molecular variants 1,4,5,6-Tetrahydro-2-methyl-4-pyrimidinecarboxylic acid. Therefore, the diversity of ectoine coding Halomonas might form a cluster with a similar kind of Halomonas species. Hence, Phylogenetic analysis of 16S rRNA sequences of type strain amongst genus Halomonas revealed that type strains AJ261, 1H9, M8, 5-3, RS-16, AAD6, SS20, 11S, NTU-107, TBZ21, 5CR, F8-11, SL014B-69, TBZ202, KCTC 42685, Z-7009, SL014B-85, CIP 105456, 204, KMM 1376, 10-C-3, Hwa etc., (Figure 4) were clustered together. It suggests that those species have a similar gene pool regardless of their genome length forms cluster. Variation in some clusters may occur due to the use of single 16S rRNA genes for phylogenetic analysis. Hence, members of the genus Halomonas might possess similar single-copy ectoine coding genes reveals that apart from the 16S RNA gene.

\section{Identification of protein families, single copy genes and pearson correlation}


Whole-genome analyses and annotation have resolved the misery of uniqueness amongst Halomonas spp. The radar chart shows that existing genomic data of Halomonas spp., possesses complete genome sequences, reference genomes and some scaffolds (Figure 5). Available genomic sequence data shows a similar gene pool and all ectoine-coding sequences from 93 type strains not having sets of genes. To resolve this issue and find relevant species in the genus Halomonas, we, therefore, annotated all genomes and identified the single-copy gene that codes ectoine. It was noticed that few Halomonas species that more than 11 single copy ectoine-coding genes. Therefore, inferred ML tree (Figure 6) some type strains shows that ectoine biomarker (in 1H9, F9-6, AJ261, SP4, ACAM 71, 62, Hb3, DSM 15911, N12, NTU-107, G-16.1, ZJ2214, TBZ3, M29, 79, BJGMM-B45, LCB169, CFH 9008, AIR-2, DQD2-30, 4A, SL014B-69, TBZ202, DX6, 9-2 and MC28) possessed by species were more or less similar kind of representative species similar to concatenated sequence of 32 Halomonas species (Figure 1). It was observed that of the 93 annotated genome sequences, $31+1$ (32) species have 11 ectoine coding genes (DoeA-DoeCDoeX-EctC-EctD-EutB-EutC-TeaA-TeaB-TeaC-UspA) as single copy number genes (Figure 7; Table 1). Heatmap of 11 ectoine coding genes shows high degree of pearson correlation (Figure 2$)$ value lies between 0.50 and $\pm 1(0=$ no correlation, $1=$ high degree correlation).

\section{Novel Universal stress protein in Ectoine TRAP cluster (UspA) and resistance mediated by UspA gene}

Studies on genome sequence analyses and analysis of various ectoine coding in Halomonas spp., uncovered that type strains viz. H. aestuarii Hb2 (NZ_CP018139), H. anticariensis DSM 16096 (GCF_000409775), H. azerbaijanica TBZ202 (GCF_004551485), H. bachuensis DX6 (GCA_011742165), H. beimenensis NTU-111 (NZ_CP021435), H. campisalis SS10MC5 (NZ_CP065435), H. caseinilytica DSM 18067 (GCF_001662285), H. cerina CECT 7282 (GCF_014192215), H. cupida (GCF_900142755), $H$. daqingensis CGMCC 1.6443 (GCF_900108215), H. denitrificans DSM 18045 (GCF_003056305), $H$. endophytica MC28 (GCF_002879615), H. eurihalina MS1 (GCF_008274785), H. gudaonensis (GCF_900100195), $H$. halmophila NBRC 15537 (GCF_006540005), H. heilongjiangensis 9-2 (GCF_003202165), H. huangheensis BJGMM-B45 (NZ_CP013106), H. kenyensis DSM 17331 (GCF_013697085), H. korlensis CGMCC 1.6981 (GCF_900116705), H. lactosivorans KCTC 52281 (GCF_003254665), H. litopenaei SYSU ZJ2214 (GCF_003045775), H. niordiana ATF 5.4 (GCF_004798965), H. organivorans CECT 5995 (GCF_014192055), H. pacifica (GCF_007989625), H. qijiaojingensis KCTC 22228 (GCF_014651875), H. saliphila LCB169 (GCF_002930105), H. stenophila CECT 7744 (GCF_014192275), $H$. taeanensis (GCF_900100755), H. urmiana TBZ3 (GCF_005780185), H. ventosae(GCF_004363555), H. xinjiangensis TRM 0175 (GCF_000759345) and $H$. zincidurans B6 (GCF_000731955) possess superfamily of conserved gene - UspA - suggests that the UspA gene/domain has been inherited from ancient protein family found in primitive bacteria. UspA protein helps Halomonas species provide support and assist Halomonas to function and produce ectoine in the saline environment under stressful conditions like high salt, low water activity and low temperature etc. Hence, UspA - stress protein - found in 32 species is a new report in the genus Halomonas.

\section{Conclusion}

Ectoine signatures can be found in 93 Halomonas genome sequences that are publicly available. 32 Halomonas species have 11 separate ectoine genes in a single copy number in their genomes, which help Halomonas spp. produce ectoine under stressful conditions. Based on existing genomic data, it was discovered that Halomonas elongata $1 \mathrm{H} 9$ has distinct ectoineproducing machinery from other Halomonas species. The existence of 11 distinct genes in 32 species, including the UspA gene, suggests that Halomonas species evolved directly from their primitive ancestor, shedding light on their evolutionary significance.

\section{Limitations}

A possible restriction would be the presence of biomarkers other than existing ectoine-coding genes responsible for Halomonas spp. producing 1,4,5,6-Tetrahydro-2-methyl-4-pyrimidinecarboxylic acid.

\section{Abbreviations}


CDS = Coding Sequence/the coding region of the gene

DoeA $=$ Ectoine hydrolase

DoeC $=$ Aspartate-semialdehyde dehydrogenase $\mathrm{DoeC}$ in ectoine degradation (EC 1.2.1.11)

DoeX = DNA-binding protein DoeX, ectoine utilization regulator

EctC $=$ L-ectoine synthase $(E C$ 4.2.1.108)

EctD $=$ Ectoine hydroxylase

EutB $=$ Ectoine utilization protein EutB, threonine dehydratase-like

EutC $=$ Ectoine utilization protein EutC, similar to ornithine cyclodeaminase

ICNP = the International Code of Nomenclature of Prokaryotes

LPSN = List of Prokaryotic names with Standing in Nomenclature

$\mathrm{MCL}=$ The Markov Cluster Algorithm

$\mathrm{ME}=$ Minimum Evolution method

MEGA X = Molecular Evolutionary Genetics Analysis across computing platforms version 10.0

MEGA X = Molecular Evolutionary Genetics Analysis, Version 10

$\mathrm{ML}=$ Maximum-Likelihood method

$\mathrm{NCBI}=$ National Center for Biotechnology Information

$\mathrm{NJ}=$ Neighbor-Joining method

NMPDR = National Microbial Pathogen Database Resource

PLfams $=$ Genus-specific families

RAST $=$ Rapid Annotation using Subsystem Technology

rRNA = ribosomal RNA

spp. $=$ species

TeaA = Ectoine/hydroxyectoine TRAP transporter substrate-binding periplasmic protein TeaA

TeaB = Ectoine/hydroxyectoine TRAP transporter small permease protein TeaB

TeaC = Ectoine/hydroxyectoine TRAP transporter large permease protein TeaC

UspA = Universal stress protein UspA in Ectoine TRAP cluster

\section{Declarations}

\section{Ethics approval and consent to participate}


Not applicable

\section{Consent for Publication}

Not applicable

\section{Availability of data and material}

Data is available within this manuscript.

\section{Competing interests}

The author declares no competing interests.

\section{Funding}

BR has used personal funds for this work.

\section{Authors' contributions}

BR conceived the original idea, collected the data, analyses, prepared figures, writing of entire manuscript. BR, WJL and RPD have revised and critically evaluated the drafts. All authors read and approved the final manuscript.

\section{Acknowledgements}

BR is thankful to editors and the reviewers for their comment to improve manuscript in present form.

\section{References}

1. Galinski, E.A., Pfeiffer, H.P., \& Truper, H.G. 1985. 1,4,5,6-Tetrahydro-2-methyl-4-pyrimidinecarboxylic acid. European J. Biochem. 149: 135-139. https://doi.org/10.1111/j.1432-1033.1985.tb08903.x

2. Cánovas, D., Vargas, C., Csonka, L.N., Ventosa, A., \& Nieto, J.J. 1996. Osmoprotectants in Halomonas elongata: highaffinity betaine transport system and choline-betaine pathway. J. Bacteriol. 178: 7221-7226. doi:

10.1128/jb.178.24.7221-7226

3. LPSN-List of Prokaryotic names with Standing in Nomenclature. https://Ipsn.dsmz.de/ Assessed on 21 April 2021

4. Melmer, G., \& Schwarz, T. (2009). Ectoines: a new type of compatible solutes with great commercial potential. Extremophiles - Vol. II, Encyclopedia of Life Support Systems (EOLSS), pp382. ISBN: 978-1-905839-93-3 (eBook), ISBN: 978-1-84826-993-4 (Print)

5. Pastor, J.M., Salvador, M., Argandoña, M., Bernal, V., Reina-Bueno, M., Csonka, L. N., Iborra, J. L., Vargas, C., Nieto, J. J., \& Cánovas, M. 2010. Ectoines in cell stress protection: Uses and biotechnological production. Biotech. Adv. 28: 782-801. https://doi.org/10.1016/j.biotechadv.2010.06.005

6. Vargas, C., Argandoña, M., Reina-Bueno, M., Rodríguez-Moya, J., Fernández-Aunión, C., \& Nieto, J.J. 2008. Unravelling the adaptation responses to osmotic and temperature stress in Chromohalobacter salexigens, a bacterium with broad salinity tolerance. Aqua Biosyst. 4: 14. https://doi.org/10.1186/1746-1448-4-14

7. RAST-Rapid Annotation using Subsystem Technology, v2.0. (https://rast.nmpdr.org/) Assessed on 15 April 2021

8. NCBI-National Center for Biotechnology Information. https://www.ncbi.nlm.nih.gov/ Assessed on 21 April 2021

9. Brettin, T., Davis, J. J., Disz, T., Edwards, R. A., Gerdes, S., Olsen, G. J., Olson, R., Overbeek, R., Parrello, B., Pusch, G. D., Shukla, M., Thomason, J. A., 3rd, Stevens, R., Vonstein, V., Wattam, A. R., \& Xia, F. 2015. RASTtk: a modular and extensible implementation of the RAST algorithm for building custom annotation pipelines and annotating batches of genomes. Sci. Rep. 5: 8365. https://doi.org/10.1038/srep08365 


\section{Table}

Table 1. Functions of ectoine-coding genes in the Genus Halomonas under different scenarios 


\begin{tabular}{|c|c|c|c|c|c|}
\hline $\begin{array}{l}\text { Gene } \\
\text { Symbol }\end{array}$ & $\begin{array}{l}\text { Gene Description/ } \\
\text { Accepted name }\end{array}$ & $\begin{array}{l}\text { EC } \\
\text { Number }\end{array}$ & $\begin{array}{l}\text { KEGG Id (KO) } \\
\text { \& Name }\end{array}$ & $\begin{array}{l}\text { Gene name in Patric } \\
\text { Server }\end{array}$ & $\begin{array}{l}\text { Comment/ Involved } \\
\text { in Pathways \& } \\
\text { KEGG KO ld }\end{array}$ \\
\hline DoeA & ectoine hydrolase DoeA & 3.5.4.44 & - & Ectoine hydrolase & $\begin{array}{l}\text { The enzyme, } \\
\text { found in some } \\
\text { halophilic bacteria, } \\
\text { is involved in the } \\
\text { degradation of the } \\
\text { compatible solute } \\
\text { ectoine. } \\
\text {. The enzyme, } \\
\text { which belongs to } \\
\text { peptidase family } \\
\text { M24, only acts in } \\
\text { the direction of } \\
\text { ectoine hydrolysis. } \\
\\
\text { smalso produces } \\
\text { (2S)-4-acetamido-2- } \\
\text { aminobutanoate, } \\
\text { which is recycled } \\
\text { back to ectoine by } \\
\text { EC } 4.2 .1 .108\end{array}$ \\
\hline DoeC & $\begin{array}{l}\text { Aspartate- } \\
\text { semialdehyde } \\
\text { dehydrogenase }\end{array}$ & 1.2.1.11 & - & $\begin{array}{l}\text { Aspartate- } \\
\text { semialdehyde } \\
\text { dehydrogenase DoeC } \\
\text { in ectoine degradation }\end{array}$ & $\begin{array}{l}\text { - Threonine and } \\
\text { Homoserine } \\
\text { Biosynthesis } \\
\text {. Lysine } \\
\text { Biosynthesis DAP } \\
\text { Pathway, GJO } \\
\text { scratch } \\
\text { - Lysine } \\
\text { Biosynthesis DAP } \\
\text { Pathway }\end{array}$ \\
\hline DoeX & $\begin{array}{l}\text { DNA-binding protein } \\
\text { DoeX, ectoine } \\
\text { utilization regulator }\end{array}$ & $\begin{array}{l}\text { No EC } \\
\text { recorded }\end{array}$ & $\begin{array}{l}\text { K15782 \& } \\
\text { Lrp/AsnC } \\
\text { family } \\
\text { transcriptional } \\
\text { regulator, } \\
\text { regulator of } \\
\text { ectoine- } \\
\text { degradation } \\
\text { genes }\end{array}$ & $\begin{array}{l}\text { DNA-binding protein } \\
\text { DoeX, ectoine } \\
\text { utilization regulator }\end{array}$ & $\begin{array}{l}\text { Glycine, serine and } \\
\text { threonine } \\
\text { metabolism } \\
\text { - Monobactam } \\
\text { biosynthesis } \\
\text {. Cysteine and } \\
\text { methionine } \\
\text { metabolism } \\
\text { - Lysine } \\
\text { biosynthesis } \\
\text { - Metabolic } \\
\text { pathways } \\
\text {. Biosynthesis of } \\
\text { secondary } \\
\text { metabolites } \\
\text {. Microbial } \\
\text { metabolism in } \\
\text { diverse } \\
\text { environments }\end{array}$ \\
\hline EctC & Ectoine synthase & 4.2.1.108 & - & $\begin{array}{l}\text { L-ectoine synthase (EC } \\
4.2 .1 .108)\end{array}$ & $\begin{array}{l}\text { Ectoine is an } \\
\text { osmoprotectant that } \\
\text { is found in } \\
\text { halophilic } \\
\text { eubacteria. }\end{array}$ \\
\hline
\end{tabular}




\begin{tabular}{|c|c|c|c|c|c|}
\hline & & & & & $\begin{array}{l}\text { This enzyme is } \\
\text { part of the ectoine } \\
\text { biosynthesis } \\
\text { pathway and only } \\
\text { acts in the direction } \\
\text { of ectoine } \\
\text { formation. }\end{array}$ \\
\hline \multirow[t]{3}{*}{ EctD } & \multirow[t]{3}{*}{ Ectoine hydroxylase } & \multirow[t]{3}{*}{ 1.14.11.55 } & \multirow[t]{3}{*}{-} & \multirow[t]{3}{*}{ Ectoine hydroxylase } & $\begin{array}{l}\text { The enzyme, } \\
\text { found in bacteria, is } \\
\text { specific for ectoine }\end{array}$ \\
\hline & & & & & $\begin{array}{l}\text { Glycine, serine and } \\
\text { threonine } \\
\text { metabolism }\end{array}$ \\
\hline & & & & & $\begin{array}{l}\text { - Metabolic } \\
\text { pathways }\end{array}$ \\
\hline \multirow[t]{2}{*}{ EutB } & \multirow[t]{2}{*}{$\begin{array}{l}\text { Ethanolamine } \\
\text { ammonia-lyase large } \\
\text { subunit }\end{array}$} & \multirow[t]{2}{*}{ 4.3.1.7 } & \multirow[t]{2}{*}{-} & \multirow[t]{2}{*}{$\begin{array}{l}\text { Ectoine utilization } \\
\text { protein EutB, threonine } \\
\text { dehydratase-like }\end{array}$} & $\begin{array}{l}\text { Glycerophospholipid } \\
\text { metabolism }\end{array}$ \\
\hline & & & & & $\begin{array}{l}\text { - Metabolic } \\
\text { pathways }\end{array}$ \\
\hline \multirow[t]{2}{*}{ EutC } & \multirow[t]{2}{*}{$\begin{array}{l}\text { Ethanolamine } \\
\text { ammonia-lyase small } \\
\text { subunit }\end{array}$} & \multirow[t]{2}{*}{ 4.3.1.7 } & \multirow[t]{2}{*}{-} & \multirow[t]{2}{*}{$\begin{array}{l}\text { Ectoine utilization } \\
\text { protein EutC, similar to } \\
\text { ornithine } \\
\text { cyclodeaminase }\end{array}$} & $\begin{array}{l}\text { Glycerophospholipid } \\
\text { metabolism }\end{array}$ \\
\hline & & & & & $\begin{array}{l}\text { - Metabolic } \\
\text { pathways }\end{array}$ \\
\hline TeaA & $\begin{array}{l}\text { TRAP transporter } \\
\text { substrate-binding } \\
\text { protein }\end{array}$ & $\begin{array}{l}\text { No EC } \\
\text { recorded }\end{array}$ & $\begin{array}{l}\text { K11688 \& C4- } \\
\text { dicarboxylate- } \\
\text { binding } \\
\text { protein (DctP) }\end{array}$ & $\begin{array}{l}\text { Ectoine/hydroxyectoine } \\
\text { TRAP transporter } \\
\text { substrate-binding } \\
\text { periplasmic protein } \\
\text { TeaA }\end{array}$ & - \\
\hline TeaB & $\begin{array}{l}\text { Ectoine/hydroxyectoine } \\
\text { TRAP transporter small } \\
\text { permease protein }\end{array}$ & $\begin{array}{l}\text { No EC } \\
\text { recorded }\end{array}$ & - & $\begin{array}{l}\text { Ectoine/hydroxyectoine } \\
\text { TRAP transporter small } \\
\text { permease protein TeaB }\end{array}$ & - \\
\hline \multirow[t]{2}{*}{ TeaC } & \multirow{2}{*}{$\begin{array}{l}\text { Ectoine/hydroxyectoine } \\
\text { TRAP transporter large } \\
\text { permease protein }\end{array}$} & \multirow{2}{*}{$\begin{array}{l}\text { No EC } \\
\text { recorded }\end{array}$} & K11690 & \multirow{2}{*}{$\begin{array}{l}\text { Ectoine/hydroxyectoine } \\
\text { TRAP transporter large } \\
\text { permease protein TeaC }\end{array}$} & - \\
\hline & & & $\begin{array}{l}\text { C4- } \\
\text { dicarboxylate } \\
\text { transporter, } \\
\text { DctM subunit }\end{array}$ & & \\
\hline UspA & $\begin{array}{l}\text { Universal stress protein } \\
\text { A }\end{array}$ & $\begin{array}{l}\text { No EC } \\
\text { recorded }\end{array}$ & & $\begin{array}{l}\text { Universal stress protein } \\
\text { UspA in Ectoine TRAP } \\
\text { cluster }\end{array}$ & - \\
\hline
\end{tabular}

\section{Figures}




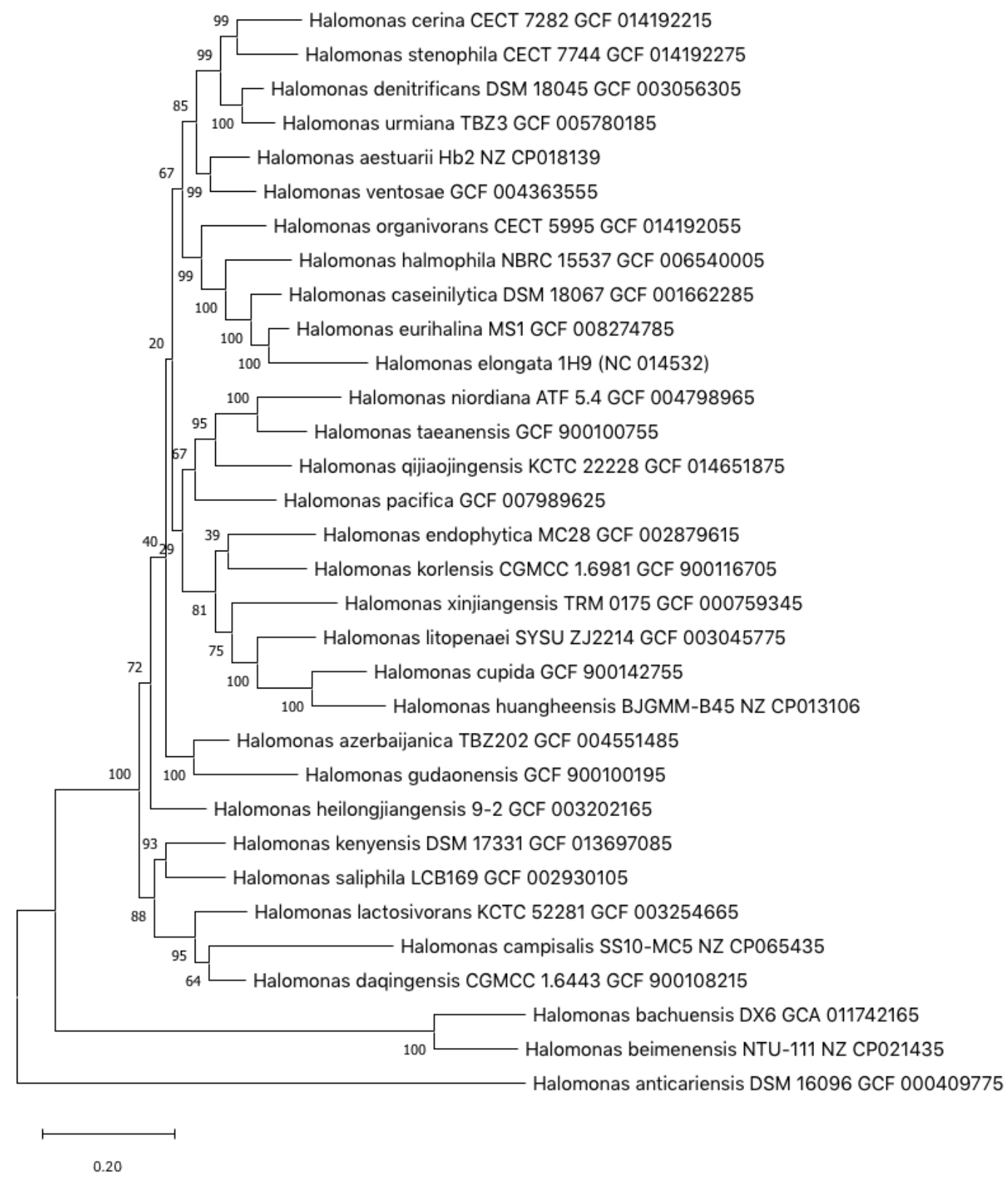

Figure 1

Maximum-likelihood (ML) analysis of concatenated sequences of 11 genes (DoeA-DoeC-DoeX-EctC-EctD-EutB-EutC-TeaATeaB-TeaC-UspA) from 32 Halomonas species in MEGA X. The evolutionary distances were computed using the Jukes-Cantor method and are in the units of the number of base substitutions per site. The percentage of replicate trees in which the associated taxa clustered together in the bootstrap test (1000 replicates).

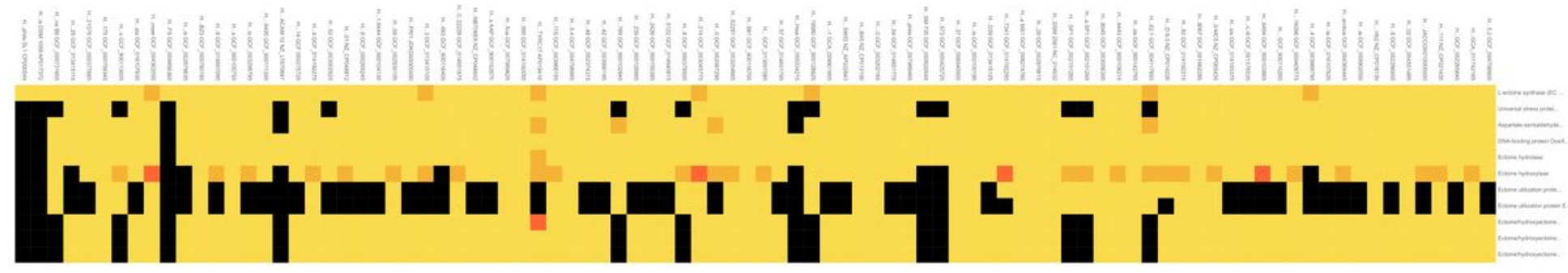

Figure 2 
Heatmap of 11 ectoine coding genes in Halomonas spp., showing genome and protein-pairwise average linkage using pearson correlation

\section{Subsystem Coverage}

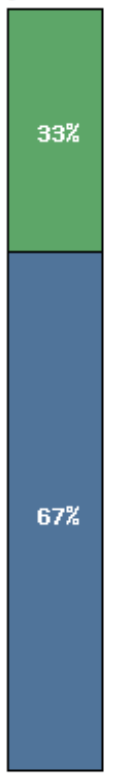

Subsystem Category Distribution

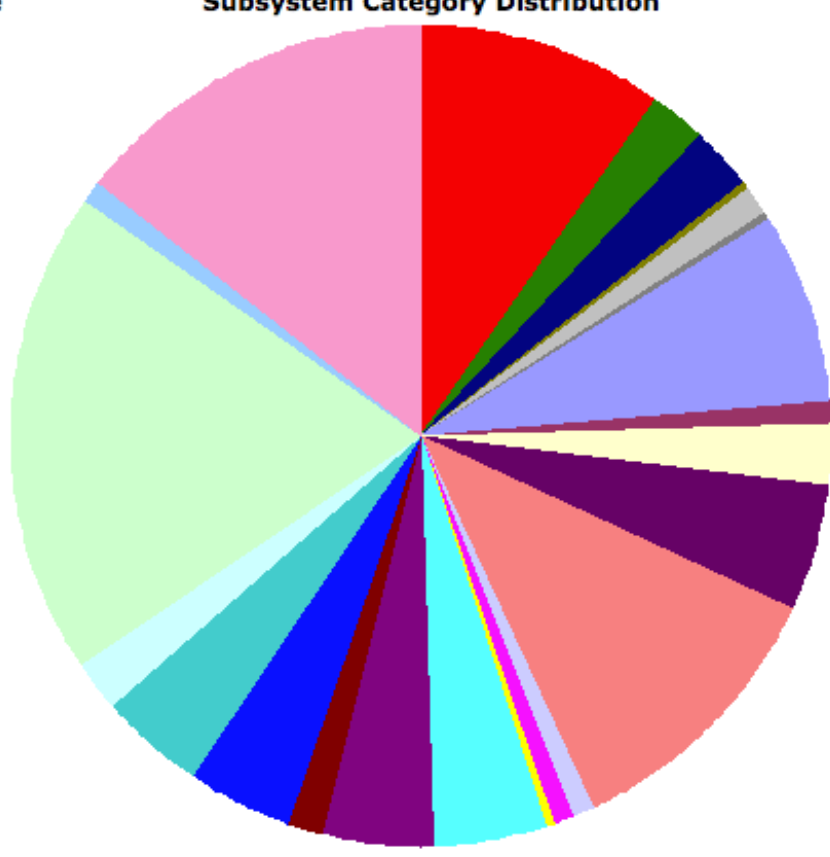

Subsystem Feature Counts

$\boxplus$ Cofactors, Vitamins, Prosthetic Groups, Pigments (178)

(I) Cell Wall and Capsule (41)

$\boxplus$ Virulence, Disease and Defense (45)

$\boxplus$ Potassium metabolism (8)

I] Photosynthesis (0)

$\boxplus$ Miscellaneous (16)

I Phages, Prophages, Transposable elements, Plasmids (6)

Ð⿻ Membrane Transport (139)

Iron acquisition and metabolism (13)

$\boxplus \quad$ RNA Metabolism (46)

⿴囗十 Nucleosides and Nucleotides (89)

I] Protein Metabolism (205)

Ð-Cell Division and Cell Cycle (0)

I Motility and Chemotaxis (12)

$\boxplus \square$ Regulation and Cell signaling (15)

$\boxplus \quad$ Secondary Metabolism (6)

Ð1 DNA Metabolism (82)

由 Fatty Acids, Lipids, and Isoprenoids (81)

(I) Nitrogen Metabolism (23)

$\boxplus \square$ Dormancy and Sporulation (2)

(I) Respiration (74)

$\boxplus \square$ Stress Response (77)

Ð Metabolism of Aromatic Compounds (35)

$\rightarrow$ Amino Acids and Derivatives (346)

$\rightarrow$ Sulfur Metabolism (3)

II Phosphorus Metabolism (20)

由ـ Carbohydrates (252)

\section{Figure 3}

RAST genome analysis of Halomonas elongata $1 \mathrm{H} 9$ 


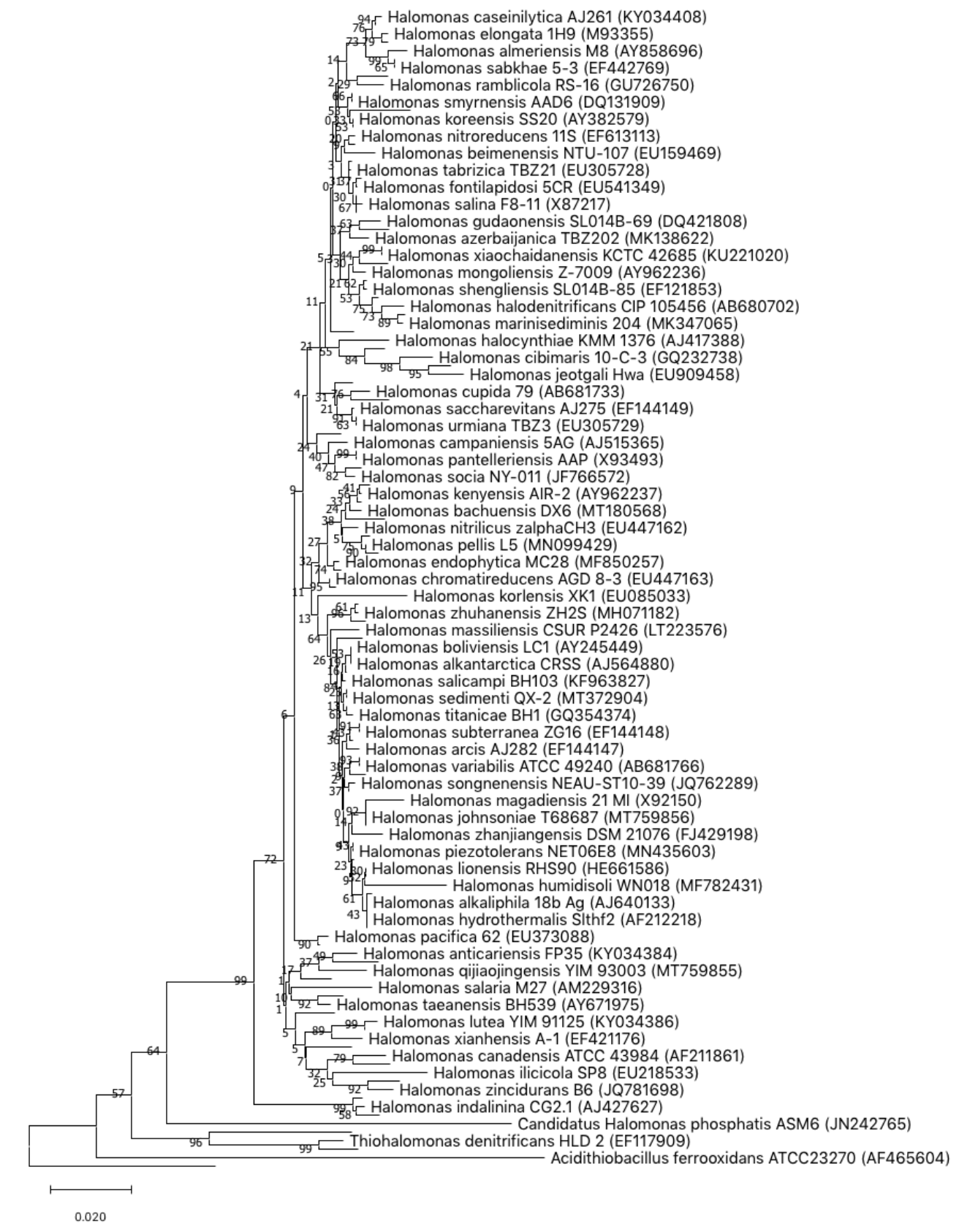

\section{Figure 4}

The evolutionary history of Halomonas species was inferred using the Neighbor-Joining method. Analysis using 16S rRNA gene sequences were conducted in MEGA X. The evolutionary distances were computed using the Jukes-Cantor method and are in the units of the number of base substitutions per site. The percentage of replicate trees in which the associated taxa clustered together in the bootstrap test (1000 replicates). 


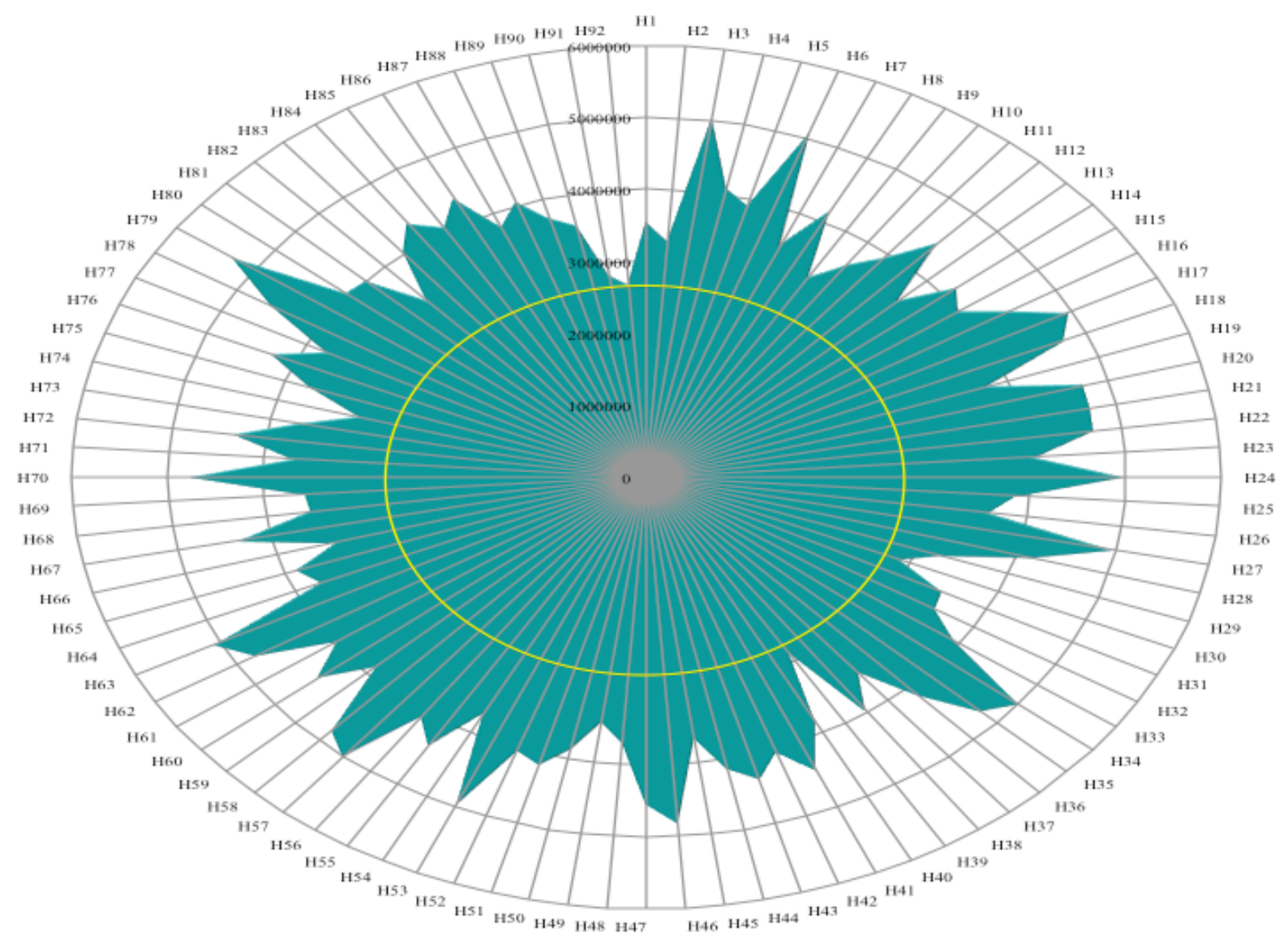

\section{Figure 5}

RADAR Chart of Genus Halomonas spp. (see supplementary table F1 for names of the species). Yellow circle indicates average genome length of each species. 


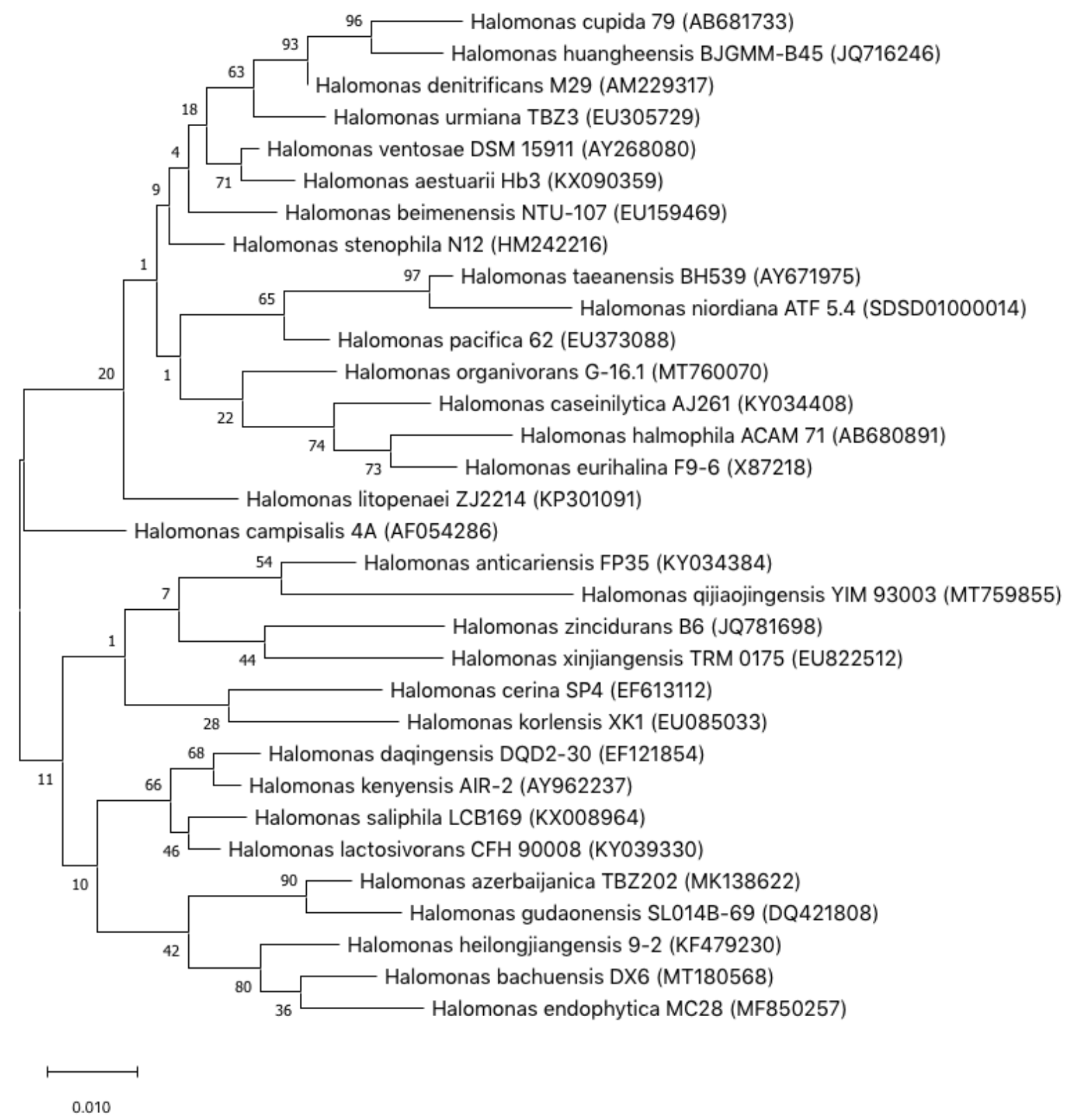

Figure 6

Maximum-likelihood analysis among Halomonas species was inferred from 16S rRNA gene sequences in MEGA X. The evolutionary distances were computed using the Jukes-Cantor method and are in the units of the number of base substitutions per site. The percentage of replicate trees in which the associated taxa clustered together in the bootstrap test (1000 replicates). 


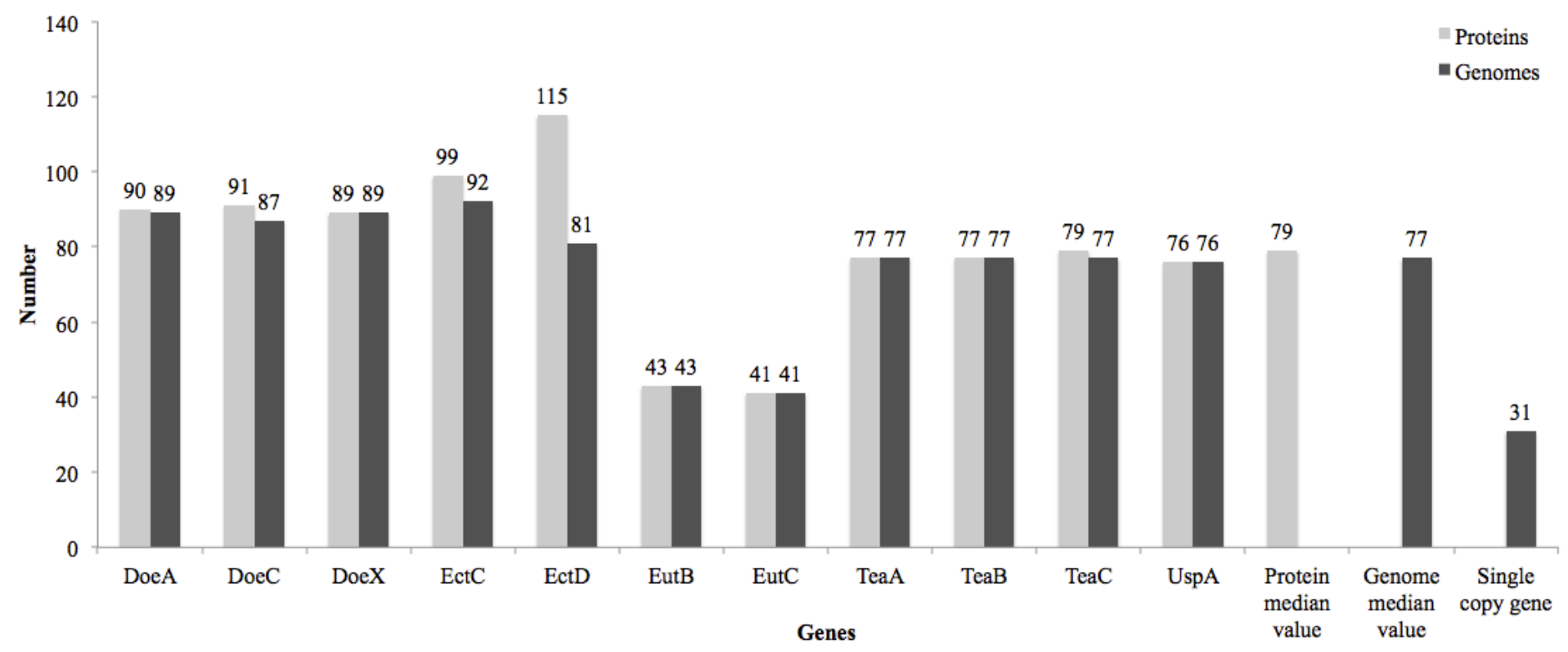

Figure 7

Single copy ectoine coding genes in the genus Halomonas

\section{Supplementary Files}

This is a list of supplementary files associated with this preprint. Click to download.

- Tables1.csv 